Hydrol. Earth Syst. Sci. Discuss., doi:10.5194/hess-2016-44, 2016

Manuscript under review for journal Hydrol. Earth Syst. Sci.

Published: 18 February 2016

(c) Author(s) 2016. CC-BY 3.0 License.

\title{
Hydrological Modeling in an Ungauged Basin of Central Vietnam Using SWAT Model
}

\author{
Ammar Rafiei Emam ${ }^{1}$, Martin Kappas $^{1}$, Linh Hoang Khanh Nguyen ${ }^{2}$, Tsolmon Renchin ${ }^{3}$ \\ $5 \quad{ }^{1}$ Department of Cartography, GIS and Remote Sensing, Georg-August University Goettingen, Germany \\ ${ }^{2}$ Faculty of Land Resources and Agricultural Environment (FLRAE) Hue University of Agriculture and Forestry (HUAF), \\ Vietnam \\ ${ }^{3}$ Remote Sensing and Space Science Laboratory, National University of Mongolia (NUM), Mongolia
}

Correspondence to: A. Rafiei Emam (rafiei99@gmail.com)

10 Abstract. Hydrological modeling of ungauged basins which have a high risk of natural hazards (e.g., flooding, droughts) is always imperative for policymakers and stakeholders. The Aluoi district in Hue province is a representative case study in Central Vietnam, as it is under extreme pressure of natural and anthropogenic factors. Flooding, soil erosion and sedimentation are the main hazards in this area, which threaten socio-economic activities not only in this district but also those of the area downstream. To evaluate the water resources and risk of natural hazards, we used Soil and Water

15 Assessment Tools (SWAT) to set up a hydrological model in the ungauged basin of Aluoi district. A regionalization approach was used to predict the river discharge at the outlet of the basin. The model was calibrated in three time scales: daily, monthly and yearly by river discharge, actual evapotranspiration (ETa) and crop yield, respectively. The model was calibrated with Nash-Sutcliff and an $\mathrm{R}^{2}$ coefficients greater than 0.7 , in daily and monthly scales, respectively. In the yearly scale, the crop yield inside the model was calibrated and validated with RMSE less than 2.4 ton/ha, which showed the high

20 performance of the model. The water resource components were mapped temporally and spatially. The outcomes showed that the highest mean monthly surface runoff, 700 to $765 \mathrm{~mm}$, between September and November, resulted in extreme soil erosion and sedimentation. The monthly average of actual evapotranspiration was the highest in May and lowest in December. Furthermore, installing "Best Management Practice" (BMPs) reduced surface runoff and soil erosion in agricultural lands. However, using event-based hydrological and hydraulically models in the prediction and simulation of flooding events is recommended in further studies.

\section{Introduction}

Hydrological modeling of water cycle in areas with extreme events and natural hazards (e.g., flooding, droughts) is imperative for sustainable management of soil and water resources. In recent years, the hydrological behavior of watersheds in Vietnam is changing due to anthropogenic factors. The evidence of this comes from rising of soil erosion, surface runoff 
Hydrol. Earth Syst. Sci. Discuss., doi:10.5194/hess-2016-44, 2016

Manuscript under review for journal Hydrol. Earth Syst. Sci.

Published: 18 February 2016

and floods in Central Vietnam. There is not any comprehensive framework to mitigate the environmental hazards in this area; therefore, we created a hydrological model of Central Vietnam with a case study in the area of Aluoi district in Hue province.

Understanding water resources availability would help stakeholders and policymakers to plan and develop an area. There are

5 various hydrological models that can estimate water resource availability (e.g., lumped models, physical distributed models, empirical models, statistical models). Among these, distributed hydrological models can simulate water balance spatially based on various soils, land uses, topography and climate conditions. One of these hydrological models is SWAT (Arnold et al., 1998), which is tested in various world climates from arid and semi-arid regions (Perrin et al., 2012; Rafiei Emam et al., 2015a) to humid and tropical areas (Alansi et al., 2009; Nguyen and Kappas, 2015). Moreover, it is able to simulate water

10 resources in large scales to regional scales. For example Schuol et al. (2008) estimated blue and green water availability in the African continent. Phuong et al. (2014) evaluated the surface runoff and soil erosion in a regional area in Vietnam.

Surface runoff, soil erosion and flooding are the main issues in humid and tropical areas due to heavy rainfall (Labrière et al. 2015). Various researchers have studied climate variabilities and human activities on soil erosion, water quality and hydrological process (Cerda` et al., 1998; Xu et al., 2013)

15 Vietnam's tropical region is very prone to soil erosion and surface runoff. Approximately $40 \%$ of natural areas are at risk of erosion (Nguyen, 2010). In recent years, most of the forested areas, particularly in Central Vietnam, were converted into agricultural lands, which resulted in surface runoff and soil erosion (Phuong and Chuong, 2013). The Aluoi district in Central Vietnam is under high socio-economic pressure, which resulted in various natural hazards such as flooding and soil erosion. Lack of data is one of the main obstacles for policymakers in this area. The main goal of this research is to set up a

20 hydrological model in the Aluoi area as a representative case study of Central Vietnam and to simulate the water balance components (e.g., water yield, soil moisture, actual evapotranspiration) in order to understand the status of water resources in this area. Assessments of surface runoff, soil erosion and flooding are the further goals of this study. Finally, we presented the best management practices adapted to Aluoi area to reduce surface runoff and soil erosion.

In this study, we used SWAT, which is a hydrological and physically distributed model. More details about SWAT model are presented in Arnold et al., (1998) and Neitsch et al., (2011).

\section{Material and methods:}

\subsection{Study area}

The study area is the Aluoi district, which is located in the center of Vietnam. The average of rainfall in this area varies from $2228 \mathrm{~mm}$ to $5495 \mathrm{~mm}$ per annum. According to the Soil Taxonomic classification (Soil Survey Staff, 2014), Ferralic

30 Acrisols is the dominant soil type in the Aluoi district. There are Humic Acrisols and Lithic Leptosols types in the northwestern and southeastern part of Aluoi as well. Forest covers approximately 90\% of the Aluoi area. The rest are 
Hydrol. Earth Syst. Sci. Discuss., doi:10.5194/hess-2016-44, 2016

Manuscript under review for journal Hydrol. Earth Syst. Sci.

farmlands (e.g., Paddy Rice, Cassava), bare lands and residential lands. The elevation of the Aluoi district varies from 38.5 meters in the northeast to 1774.5 meters above sea level in the north.

The Aluoi district consists of three watersheds. The first watershed is located in the south of Aluoi, where the main river, called the "Xe Khong River," flows toward Laos. This watershed has an area of approximately $542 \mathrm{~km}^{2}$. The second

5 watershed is situated in the north of Aluoi and the main river, Song Sia River, flows into the "Tam Giang lagoon". The watershed has an area of approximately $410 \mathrm{~km}^{2}$. The third watershed in the east of Aluoi district has an area of approximately $506 \mathrm{~km}^{2}$. The river in this watershed, called "Song Huu Trach River," flows into the "Song Huong lagoon." Fig. 1 shows Aluoi district including watershed borders, climate and hydrometric stations around the district. We selected the second watershed in the Aluoi district for our case study because it is the main sub-watershed in Aluoi district with various land use classes.

\subsection{Data preparations}

There are three climate stations around the study area with monthly data, and one station inside the Aluoi district with daily data. There are no hydrometric stations inside or at the outlet of the Aluoi district. The closest hydrometric station to Aluoi, called "Thuong Nhat," is located east of the study area. The river discharge of this station is used in regionalization and the

15 prediction of river discharge in our study area. The FAO-soil map (FAO, 2003) was improved based on local soil data and was also used in this study. This soil map contains information for two soil depths: in topsoil $(0-30 \mathrm{~cm})$ and subsoil (30100cm). Land use statistics in 2010 was obtained from Department of Natural Resources and Environment in Thua Thien Hue Province. The land use statistics contains different classes such as protected forest area, evergreen forests, bare lands, residential area, paddy rice lands and other agricultural lands. Digital Elevation model (DEM) was derived from SRTM with

$2030 \mathrm{~m}$ resolution. Daily climate data such as daily rainfall, maximum and minimum temperature, solar radiation, and relative humidity, was used from the Aluoi climate station, which is situated in the center of the Aluoi district (Fig. 1). Daily climate data from the Aluoi station is available from 2005 to 2013. Crop schedule and yield data were used to simulate crop growth in SWAT. MODIS time series data were used to extract monthly evapotranspiration. These data were further used to calibrate the hydrological model.

\section{$25 \quad 2.3$ Set up the hydrologic model using SWAT}

SWAT is able to predict the impact of land management practices on soil and water. Additionally, SWAT can simulate water quality and quantity as well as crop growth. The main components of the SWAT model consist of weather, hydrology, plant growth, nutrient, pesticide, bacteria and land management (Arnold et al., 1998; Neitsch et al., 2011). In this study, we focused only on the hydrologic, plant growth and land management components of the SWAT model. In SWAT, a 30 watershed is partitioned into sub-basins using DEM, which are then further subdivided into HRUs (Hydrological Response Units) with homogenous soil, land use and slop characteristics. HURs are the basis of water balance calculation. The water 
Hydrol. Earth Syst. Sci. Discuss., doi:10.5194/hess-2016-44, 2016

Manuscript under review for journal Hydrol. Earth Syst. Sci.

Published: 18 February 2016

(c) Author(s) 2016. CC-BY 3.0 License.

in each HRU can be stored in four levels: snow, soil profile (0-2m), shallow aquifer (0-2m) and deep aquifer (2-20m). Rafiei Emam et al., (2015 b) and Vilaysane et al., (2015) revealed that a single HRU could not show the characteristics of a subbasin. Therefore, we used multiple HRUs for sub-basin analysis in this research. In SWAT, a water balance calculation is simulated in two separate components: land phase and routing phase. The land phase controls the amount of water, sediment, nutrient and pesticide loadings to the main channel in each sub-basin, while the routing phase defines the movement of water, sediment and nutrient loadings from the channel networks to the outlet. The water balance is calculated in the land phase using the following Eq. (1):

$S W_{t}=S W_{0}+\sum_{i=1}^{t}\left(R_{\text {day }}-Q_{\text {surf }}-E T_{a}-W_{\text {seep }}-Q_{g w}\right)$

where $S W_{t}$ is the soil water content, $S W_{0}$ is the initial soil water content, $R_{\text {day }}$ is the amount of precipitation, $Q_{\text {surf }}$ indicates surface runoff, $E T_{a}$ shows evapotranspiration, $W_{\text {seep }}$ is the soil infiltration and $Q_{g w}$ shows the return flow.

In this study, surface runoff was simulated using a SCS curve number. The runoff curve number is an empirical parameter used for predicting direct runoff or infiltration from rainfall excess. The curve number method was developed by the USDA Natural Resources Conservation Service (USDA, 1986). SCS is widely used and is an efficient method for determining the approximate amount of direct runoff from a rainfall event in a particular area. It is based on the area's hydrologic soil group,

15 land use, treatment and hydrologic condition. Percolation was simulated with a layered storage routing technique combined with a crack flow model; and potential evapotranspiration (ETP) was simulated using the Penman-Monteith method. The actual evapotranspiration was predicted based on ETP in addition to soil and crop factors based on the methodology developed by Ritchie (1972). The daily value of the Leaf Area Index (LAI) was used to divide the ETP into potential soil evaporation and potential plant transpiration. LAI and root development were predicted by the crop growth component of

20 SWAT. In SWAT, soil erosion is calculated with MUSLE algorithm (Modified Universal Soil Loss Equation) (Williams, 1975), which is a modified version of USLE (Universal Soil Loss Equation) (Wischmeier and Smith, 1965). USLE is a function of rainfall energy, while MUSLE is a function of runoff.

In the routing phase of SWAT, water is routed using Kinematic wave model (Chow et al., 1988). SWAT assumes the main channels have a trapezoidal shape. The water depth in the channel is calculated based on the cross-sectional area of flow in

25 the channel, bottom width of the channel and the inverse of the channel side slope. For more information see Neitsch et al., (2011).

To better understand the hydrological behavior, which leads to a better calibration of the model, we used an automated digital filter program (Arnold and Allen, 1999) to separate discharge into base flow and surface runoff. Using this approach, the low-frequency base flow component was separated from high-frequency runoff components through a low-pass filter 30 (Stewart et al., 2007). Meaurio et al., (2015) used the same method to calculate a base flow constant. More details are presented by Arnold and Allen (1996). In this research, watershed was delineated into twenty sub-basins using an SRTM map and stream network in an ArcGIS environment. The area of watershed is approximately 41,000 ha. The watershed has diverse elevations from 19 to 1777 meters from the north to the west of the basin. Some 54 HRUs were created by 
Hydrol. Earth Syst. Sci. Discuss., doi:10.5194/hess-2016-44, 2016

Manuscript under review for journal Hydrol. Earth Syst. Sci.

Published: 18 February 2016

(c) Author(s) 2016. CC-BY 3.0 License.

integrating land use, soil and slope maps. Because Aluoi is a mountainous area, we estimated precipitation (PLAPS) and temperature (TLAPS) difference by elevation. PLAPS is precipitation lapse rate $\left(\mathrm{mm} \mathrm{H}_{2} \mathrm{O} / \mathrm{km}\right.$ ), and TLAPS refers to temperature lapse rate $\left({ }^{\circ} \mathrm{C} / \mathrm{km}\right)$. For this aim, all sub-basins with a difference in elevation greater than $100 \mathrm{~m}$ were selected and PLAPS and TLAPS were applied. The PLAPS and TLAPS were estimated at $243.2 \mathrm{~mm}$ and $-5.8^{\circ} \mathrm{C}$ per $\mathrm{km}$. Rice is the dominant agriculture crop in Aluoi, therefore the crop schedule for rice was applied to the model. Rice is cultivated two times per year: from summer to autumn and winter to spring.

\subsection{Calibration, validation and uncertainty analysis}

The Aluoi district is ungauged by hydrometric stations; therefore, to calibrate the models we used different approaches:

\subsubsection{Regionalization and river discharge calibration}

10 The hydrological model's parameters for ungauged basins (i.e., without any river discharge measurements) can be predicted using regionalization method (Vandewiele, 1995; Bardossy, 2007). Usually watersheds with similar characteristics show similar hydrological treatments and therefore the hydrological parameters can be transferred from the same watersheds. This transformation is called regionalization. A number of basin characteristics (e.g., soil, topography, land use, precipitation, and temperature) were presented in Samaniego and Bardossy (2005). There are different methods for this transformation including regression methods (Kokkonen et al., 2003; Bastola et al., 2008), spatial proximity (Merz and Blöshla, 2004) and physical similarity (McIntyre et al., 2005). One can also use the ratio method to predict river discharge in ungauged basins. Parajka et al., (2005) used geostatistical methods (i.e., Kriging) to transfer model parameters. Sun et al., (2012) used a new approach to calibrate hydrological parameters in ungauged basins. They used the river water level obtained from satellite radar altimetry observations at the outlet of the basin instead of river discharge. In another work, Sun et al., (2010) used the

20 river flow width obtained through satellite observation as a surrogate for river discharge records to calibrate a hydrological model.

To predict the stream flow in ungauged basins, stream flow records must be available in a nearby area. We found a basin close to our study area with the same physical characteristics: the hydrometric station called "Thuong Nhat" with a surrounding watershed of $125 \mathrm{~km}^{2}$. We used the ratio method to transfer observed data from the donor catchment to our study area. After river discharge was predicted in the ungauged basin, we then used sensitive parameters to calibrate the model. The SUFI-2 algorithm (Sequential Uncertainty Fitting, ver. 2; Abbaspour, 2015) in the SWAT Cup package was used to calibrate and analyze uncertainty. Nash-Sutcliff coefficient was computed as the objective function for our river discharge analysis. In SUFI-2 all sources of uncertainty (e.g., uncertainty in input data, conceptual model and parameters) are represented in model output. The degree of uncertainty is measured by two factors: p-factor, which represents the 30 percentage of measured data bracketed by $95 \%$ prediction uncertainty (95PPU), and R-factor, which is the ratio of average 
Hydrol. Earth Syst. Sci. Discuss., doi:10.5194/hess-2016-44, 2016

Manuscript under review for journal Hydrol. Earth Syst. Sci.

Published: 18 February 2016

thickness of 95PPU to standard deviation of measured data. The model attempts to bracket most of the data (P factor=1) within a narrow band $(\mathrm{R}$ factor=0). However, often a balance must be reached between these two factors.

\subsubsection{Calibration based on crop yield}

We calibrated a crop yield because calibration using a crop yield gives more confidence on actual evapotranspiration, and

5 hence give the precise estimation of other water components such as, soil moisture, surface runoff and percolation (Faramarzi et al., 2009; Rafiei Emam, 2015b). The SUFI-2 algorithm was used to calibrate the crop parameters and uncertainty analysis. A mean square error was used as the objective function. There are several parameters that affect crop yield. These parameters include the heat unit (HU), harvest index (HI), and bio target (BIO-TARG). The HU is the amount of heat that brings plants to maturity, the $\mathrm{HI}$ is the fraction of above-ground dry biomass to yield crops, and the BIO-TARG

10 is the potential plant yield. We optimized these parameters in order to calibrate crop yield in our hydrological model.

Plant growth in the model is usually inhibited by temperature, water, nitrogen and phosphorous stress factors. Rafiei Emam et al., (2015c) evaluated the water and temperature stresses of winter wheat using a climate change model. Temperature is a very important factor for plant growth; plants can grow only if the mean temperature exceeds the base temperature of plant. The accumulation of daily mean air temperatures above the plant's optimum temperature over the plant-growth period is

15 called a heat unit. The base (or optimum) temperature varies for different plants, for instance, paddy rice has base temperature of $10^{\circ} \mathrm{C}$.

\subsubsection{Calibration based on ETa using MODIS products}

Because agriculture covers only a small part of Aluoi and most of the lands are covered by forest, we used ETa products of MODIS in order to calibrate the SWAT model. There have been several attempts to use satellite observation of

20 evapotranspiration to calibrate a hydrological model. Immerzeel and Droogers, (2008) used MODIS satellite images to calibrate the hydrological model using evapotranspiration data.

Nash-Sutcliff efficiency (NSE) and coefficient of determination were used to assess the SWAT model based on ETa calibration. NSE was used as the objective function to compare the monthly observed and simulated ETa following Eq. (2):

$N S E=1-\frac{\sum_{i=1}^{n}\left(Q_{o b s}-Q_{s i m}\right)^{2}}{\sum_{i=1}^{n}\left(Q_{o b s}-\bar{Q}_{o b s}\right)^{2}}$

25 where $Q_{o b s}$ and $Q_{\text {sim }}$ are the measured and simulated data, respectively, $\mathrm{n}$ is the total number of data records and $\bar{Q}_{o b s}$ is the mean measured data.

We used MOD16 products (Mu et al., 2011) of MODIS from 2006 to 2013 on a monthly scale (http://www.ntsg.umt.edu/). We downloaded 90 images (6 images are missing) in Central Vietnam ( $h=28$ and v=7). We further extracted ETP and ETa of MOD16 products in ArcGIS environment in our study area and summarized data in each sub-basin. We analyzed the reliability of the data and further data were used to calibrate the SWAT hydrologic model. 
Hydrol. Earth Syst. Sci. Discuss., doi:10.5194/hess-2016-44, 2016

\section{Results and Discussion}

\subsection{Regionalization outcome:}

The river discharge data at the outlet of the Aluoi-II basin was predicated on the observed data from Nhat station, $45 \mathrm{~km}$ away. Data is available at daily scale from 2005 to 2010 at Nhat station. The characteristics of the two basins are similar

5 (Table 1); therefore, we used a ratio method to predict the observed data at the outlet of our study area. We multiplied the observed data on the constant value $(\beta=3.264)$ obtained through area ratio method. It is important to note that the closest climate station to Nhat basin, called Nam Dong, with average yearly precipitation of 3800 mm, is comparable to Aluoi rain gage station, which is $3900 \mathrm{~mm}$. It has $2.6 \%$ less rainfall, which can be ignored.

\subsection{Parameterization, sensitivity and uncertainty analysis}

10 The initial results of SWAT were not very good, with low paddy rice yield and unreliable ETa and river discharge. Therefore, we calibrated the model based on crop yield, ETa remotely sensed data and regionalization of river discharge.

\subsubsection{Calibration and Parameterization for River discharge}

Based on the river discharge data obtained by regionalization (i.e., ratio method), the SWAT model was calibrated at a daily time scale. We choose three years (2006-2008) for calibration and two years (2009-2010) for the validation processes with

15 one year as a warm-up period (2005). We selected the sensitive parameters based on the "one-at-a-time" method (Table 2). One-at-a-time method is executed for one parameter at a time only. Then, the global sensitivity analysis was done based on the regression method (Abbaspour, 2015). These parameters were used to calibrate the model by SWAT-CUP program.

The results of global sensitivity analysis show that effective hydraulic conductivity in the main channel (CH-K2), Base Flow Alpha Factor for Bank Storage (Alpha-BNK) and soil bulk density (SOL-BD) are the most sensitive parameters for river discharge calibration (Fig. 2). The importance of these parameters has been reported by some other researchers. Vilaysane et al., (2015) and Luo et al., (2012) revealed that the parameters of CH-K2 and Alpha-BNK play important roles in the calibration of the SWAT model in Tropical areas. It is important to note that the base flow recession constant (alpha factor) was estimated by a base flow program (Arnold and Allen, 1999) before calibration processes. The constant value for the base flow was estimated at 0.0420 and 0.0542 for the validation and calibration periods. Therefore, we put an initial range between 0.04 and 0.06 for base flow optimization.

The calibration and validation results show that there is a good agreement between the simulated daily stream flow and the observed data (Fig. 3). The model was well calibrated dynamically but the peak in some days was not simulated very well, probably due to regionalization processes. The other limitation of the model, such as the amount of water use, can also lead to this uncertainty. Vilaysane et al. (2015) presented under prediction of extreme peak flows using SWAT in a downstream 30 part of Mekong River basin in Laos. Overall, the statistical results for both calibration and validation show high NS (0.73, 
Hydrol. Earth Syst. Sci. Discuss., doi:10.5194/hess-2016-44, 2016

Manuscript under review for journal Hydrol. Earth Syst. Sci.

Published: 18 February 2016

(c) Author(s) 2016. CC-BY 3.0 License.

$0.67)$ and $\mathrm{R}^{2}(0.74,0.68)$ respectively, which demonstrates the high performance of the model. Additionally, the low $\mathrm{r}$-factor shows that the uncertainty of the model is low. Hence, the model can be used for further hydrological studies in this area. The scatter plot between observed and simulated data for both calibration and validation show the high performance of the model (Fig. 4).

\section{$5 \quad$ 3.2.2 Parameterization for crop yield}

The sub-basins with paddy rice cultivations (i.e., sub-basins located south of the Aluoi area) were selected for the parameterization of the model based on crop yield. The calibration based on crop makes model results more confident (Rafiei Emam et al., 2015b). There is a direct relationship between crop yield and evapotranspiration; therefore, the calibration of the model based on yield improves the simulation of other water components.

10 The sensitivity analysis showed that all crop parameters (e.g., HEAT-UNIT, BIO-TARG, HI) were sensitive to crop yield. Fig. 5 shows the results of calibration and validation of the paddy rice yield. As illustrated, observed yields are inside or quite close to simulated yield band, indicating good results. The yield varies between 26.5 and 30 ton/ha, with the highest yield found in the year 2010. The P-factor is quite good, with a value larger than 0.8 for calibration and 0.89 for the validation period. The large r-factor (i.e., r-factor=3) represents a large uncertainty. The reason for this amount of uncertainty

15 is probably due to low data availability and insufficient accounting for agriculture and industrial water use in the model. The other reason is due to Nitrogen $(\mathrm{N})$ stress, because the $\mathrm{N}$ could remove from the farmlands quickly by rising rainfall and surface runoff.

\subsubsection{Parameterization for ETa based on MODIS ET time series}

\section{-Reliability of MODIS data}

20 To calibrate the model based on the evapotranspiration, first we evaluated the reliability of MOD16 of MODIS time series data. Toward this aim, ETP of MOD16 was extracted monthly from January 2006 to December 2013. The average ETPMODIS in the basin was plotted against ETP calculated by measuring data in the SWAT model using the Penman-Monteith method (Fig. 6). As Fig. 6 shows, there is a high correlation between these data. The dynamics of time series of SWAT and ETP-MODIS was mapped in Fig. 7. The dynamics of ETP of SWAT and MODIS are very similar to each other, but there is

25 a bias between these data. As Figure 8 shows, the amount of ETP in winter, when there is less precipitation, is more reliable than the other months. The peak of ETP-MODIS in summer, May to August, is higher than measured data (approximately 10 to 70 percent more than measured one), which makes it unreliable in these months. Therefore, we calculated the bias between two data time series. Toward this aim, we divided the year in two periods: first from October to March and second from April to September. Then we analyzed data and found two constants for these two periods by trial and error. To correct

30 the bias, for the first period, the data was multiplied by 0.45 , and for second period, the data was multiplied by 0.70 . With the bias correction, the ETP of MODIS and SWAT would be the same. Then these bias constants were applied to ETa of 
Hydrol. Earth Syst. Sci. Discuss., doi:10.5194/hess-2016-44, 2016

Manuscript under review for journal Hydrol. Earth Syst. Sci.

Published: 18 February 2016

MODIS data as well, and further these data were used to calibrate the SWAT hydrological model. Fig. 8 shows the anomaly spatial maps of ETP extracted from MODIS-MOD16 from January to December 2013, showing the highest ETP in May and lowest ETP in December.

\section{5 -Procedure of model calibration using ET-MODIS}

In this step, the SWAT Model was calibrated in the sub-basin with dominant forest cover. In the Basin-II, there are 20 subbasins and forest is the dominant land use type in the area. We selected sub-basins with the greatest area in order to optimize the relevant parameters. To calibrate the SWAT model by ET data, first we kept the calibrated parameters for river discharge and crop yield and then we chose the parameters that affected ETa (Table 2). Five parameters were used for sensitivity

10 analysis using a one-at-a-time method. Further, these parameters were used to calibrate the SWAT model using ETa-MODIS observed data. Fig. 9 shows the dotty plots of sensitive parameter values or relative changes versus objective function based on a one-at-a-time method. The figure 10 illustrates that ESCO (Soil evaporation compensation factor) and heat units are the most sensitive parameters to ETa. ESCO depends on soil characteristics and controls the soil evaporation, whereas heat units depend on the plant's characteristics to bring them to maturity and control the amount of transpiration. BLAI represent the

15 maximum potential leaf area index. BLAI is one of the six parameters used to determine leaf area development of plants during the growing season. Moreover, we evaluated global sensitivity analysis following iterations that used the multiple regression system with a regression of the Latin hypercube-generated parameters against the objective function values. For more information about sensitivity analysis see Abbaspour, (2015). The results of the global sensitivity analysis are shown by p-value and t-test, which show the measure of sensitivity and the significance of sensitivity, respectively. The results

20 show that BLAI is the most sensitive parameter for ET calibration, among others (Fig. 10).

The results of the model calibration were satisfactory. Fig.12 shows the results of the ETa calibration in two sub-basins to the north and south of Basin-II. The ETa was calibrated between 2006 and 2010 with a one year warm-up period. As Figure 13 depicts, the observed data are captured by the predicted band (95PPU). In all of the sub-basins, the temporal changes of ETa were simulated quite well, with a Nash-Sutcliffe (NS) and coefficient of determination $\left(\mathrm{r}^{2}\right)$ higher than 0.72 . Moriasi et

25 al. (2007) and Santhi et al. (2001) reported that if the NS and $r^{2}$ are greater than 0.5, then the performance of the model is satisfactory. Figure 12 shows that the simulated ETa has variation in different seasons. Petković et al. (2015) mentioned that relative humidity and a wind speed of two meters are two factors that play a role in the variation of ET. The same results were also presented by Nguyen and Kappas (2015). As Fig. 11 shows, the lowest evapotranspiration is from November to February, when the average temperatures are lower than over the other months.

30 The scatter plot between simulated and observed monthly ET in the center of the basin shows that the correlation coefficient $\left(\mathrm{r}^{2}\right)$ in calibration and validation periods are high, with 0.84 and 0.80 , respectively (Fig. 12). 
Hydrol. Earth Syst. Sci. Discuss., doi:10.5194/hess-2016-44, 2016

\subsection{Quantification of water components:}

After the model was calibrated by river discharge, crop yield and ET, we computed the water resource availability in AluoiII watershed. The monthly water yield (i.e., the net amount of water that leaves the sub-basin and contributes to streamflow in the reach during the time period), green water resources (i.e., soil water content) and green water flow (i.e., actual

5 evapotranspiration) were calculated in the study areas (Fig. 13). We extracted water components for the time period 2006 to 2013.

There is a significant spatial variation in the hydrological components across the watershed. The distributed maps showed that in the north of basin, where the rainfall and water yield are small, actual evapotranspiration (ETa) is high. The ETa shows the amount of water that is consumed by plants. The annual average ETa (M95PPU) during the period of 2006 to

102013 varied from $717 \mathrm{~mm} /$ year to $863 \mathrm{~mm} /$ year in different parts of the watershed. The lowest amount of ETa was found in the southern area, while the northern area had the highest ETa (Fig. 13a). The soil water content map (Fig. 13b) shows the area where rain-fed Rubber and other perennial crops have a better chance of high production due to soil moisture. The southern area has the highest soil moisture, while the eastern area has the lowest soil moisture. This is probably due to soil characteristics in different parts of the watershed. Water yields (Fig. 13c) varied from $2902 \mathrm{~mm} / \mathrm{year}$ to $3405 \mathrm{~mm} / \mathrm{year}$ in

15 different sub-basins from 2006 to 2013 . Water yield is the net amount of water that leaves the sub-basin and contributes to streamflow in the reach during the time period.

The annual average of rainfall from 2006 to 2013 was $4049 \mathrm{~mm} / \mathrm{year}$. We calculated the monthly average of water components in the entire basin. The results of average monthly evapotranspiration showed that ETa is highest in May, due to the high demand of water by forests and plants in this month. The prediction uncertainty in summer is higher than in winter

20 due to the high consumption of water by plants during these months (Fig. 14a). Paddy rice lands affect the ETa considerably. The total ratio of ETa to rainfall for eight years (2006-2013) was calculated at 40\%, showing that the ETa is always less than rainfall in tropical areas. Nevertheless, this ratio is lowest in October and November and highest in February. We notice that most floods happen in October and November; therefore, the ratio is lowest in these months.

\subsection{Surface runoff and soil erosion}

25 The result of the SWAT hydrological model shows that the surface runoff is high in upstream areas of basins. Vegetation cover, soil type and slope gradient (El Kateb et al., 2013) are the important factors affecting surface runoff. Land use change and deforestation lead to increasing surface runoff and hence soil erosion. The results showed that the spatial average of surface runoff in Aluoi-II varied from $2060 \mathrm{~mm}$ /year to $2540 \mathrm{~mm} /$ year from 2006 to 2013. The area upstream has the highest amount of surface runoff probably due to its high slope. The monthly average 95PPU of surface runoff was extracted in

30 order to understand the temporal distribution and uncertainty of surface runoff (Fig. 14b). This figure reveals that October has the highest surface runoff, with an average of approximately $764 \mathrm{~mm} / \mathrm{month}$. The surface runoff during September to November has the highest uncertainty, probably due to a conceptual model and parameter uncertainties. However, all 
Hydrol. Earth Syst. Sci. Discuss., doi:10.5194/hess-2016-44, 2016

Manuscript under review for journal Hydrol. Earth Syst. Sci.

Published: 18 February 2016

uncertainties are depicted in the 95PPU band, shown in gray in the figure. As the figure shows, there is a strong relationship between surface runoff and rainfall. In February, the rainfall is the lowest and the uncertainty surface runoff prediction is also low, while in October, the month with the highest rainfall, the uncertainty is high. Surface runoff mainly occurred in areas with a slope higher than $25 \%$. This slope class includes the farmlands, which have a surface runoff larger than forest

5 land use. Nevertheless, the surface runoff in the paddy rice lands is low because the slopes in this area usually break down by terracing, therefore, the time concentration is increased. The soil erosion and sedimentation followed the surface runoff behavior. Therefore, with an increase in surface runoff, the soil erosion and hence sedimentation is increased. The same results were presented by Phuong et al., (2014). The results of sediment simulation in this area using the SWAT model show the average of sediment loads that are transported into the reach between 2006 and 2013 are from 48 tons to 2650 tons/ha.

10 Additionally, the northwestern part of the basin, which is covered by forest with slope larger than $25 \%$, has the highest sediment yield, because the high average slope leads to a high erosion and sedimentation yield. The monthly average of sediment yield predicted between 2006 and 2013 revealed that October and November have the highest sediment yield with approximately 580 ton per hectare, despite having the highest runoff. It is important to note that due to data scarcity we could not calibrate sediment simulation; therefore, we didn't present a spatial pattern of sedimentation here. The results revealed that surface runoff is highest when the amount of rainfall reaches the maximum amount during the year.

\section{3-5-Scenarios:}

\section{3-5-1-Land use change scenario}

A scenario of changing land use was implemented in order to see the influence of land use change on surface runoff. We selected a sub-basin with $22 \mathrm{~km}^{2}$ upstream and assumed a conversion of land use from forest to residential land. The results

20 showed that the average annual surface runoff increased approximately 30\%, while evapotranspiration decreased approximately 37\%. Rising surface runoff leads to increased river discharge and hence soil erosion and sedimentation in downstream parts of the basin. Increasing surface runoff by urbanization is reported by other researchers (Rafiei Emam et al., 2015c).

\section{3-5-2-Best Management Practices (BMPs)}

25 BMPs are conservation programs that minimize pasture and agricultural runoff and nutrient loads. Many researchers use BMPs to conserve agricultural and pastoral lands. For example, the effects of two BMP systems on water quality in a livestock pasture were discussed by Sheshukov et al. (2016). Smith et al. (2009) presented BMPs to conserve agricultural lands. Arabi et al. (2006) used four BMPs types in different land use classes in order to reduce sediment and nutrients loads in the watershed.

30 The southern part of the Aluoi basin has the highest runoff and hence flooding, which resulted in soil erosion and sedimentation in this area. We installed two types of BMPs structures - terracing and contouring - in agricultural lands with 
Hydrol. Earth Syst. Sci. Discuss., doi:10.5194/hess-2016-44, 2016

Manuscript under review for journal Hydrol. Earth Syst. Sci.

Published: 18 February 2016

(c) Author(s) 2016. CC-BY 3.0 License.

slope higher than $25 \%$ in early 2005 . A terrace was designed in the field to decrease runoff and protect the land against erosion. It is constructed across slope on a contour. Terracing in the SWAT model is simulated by adjusting runoff and erosion parameters such as the USLE practice factor, the slope length and curve number. A countering system simulates a contour to the HRU on a specified day. Contour planting is the method of planting crops in straight rows in small ridges. It

5 results in increased roughness and soil storage. Similar to terracing, contouring is simulated by adjusting the USLE practice factor and curve number.

The results revealed that terracing in dry agricultural lands resulted in a reducing surface runoff and sediment yield of approximately $31 \%$ and 55\%, respectively, whereas increasing ETa only increased approximately $37 \%$. The amount of soil water content also increased 146\% from 2006 to 2013. Nevertheless, implementing contouring has more significant impact

10 than terracing in farmlands with a slope of more than 25\% (Table 3). The BMPs reduce surface runoff and sedimentation, whereas percolation, soil moisture and ETa decrease. Labrière et al. (2015) mentioned that land use with good management practices has a limited influence on soil erosion. They concluded that implementations such as contour planting, no-till farming and a vegetative buffer strip can decrease soil erosion by up to $99 \%$.

\section{Conclusion}

15 A hydrological model based on SWAT was implemented in the Aluoi district in the Central Vietnam in order to assess water and land resource management and planning. A multi-calibration procedure that takes into account not only the stream flow but also the actual evapotranspiration and crop yield was investigated. The model was well calibrated based on river discharge, actual evapotranspiration and crop yield. The best approach to predict the river discharge and peak flow in ungauged basin is to use the regionalization method. We used a ratio method of regionalization in order to predict river

20 discharge and peak flow in the Aluoi ungauged basin; however, we suggest different regionalization approaches in order to transfer parameters from donor to target basins to predict river discharge data in further studies

Based on the results, surface runoff was high, probably due to the geometry of the basin and its soil properties. The results of our study show a high risk of flooding in this area, which affects human life downstream in the Aluoi district. The surface runoff is high, which leads to rising soil erosion and sedimentation. Our results show that using BMPs lead to decreased 25 surface runoff and hence soil erosion in agricultural lands. Therefore, we suggest implementing terracing/contouring systems in the steep farmlands.

\section{References}

1. Abbaspour, K.C.: SWAT-CUP: SWAT Calibration and Uncertainty Programs - A User Manual. Swiss Federal Institute of Aquatic Science and Technology, Eawag, Dubendorf, Switzerland, 2015. 
Hydrol. Earth Syst. Sci. Discuss., doi:10.5194/hess-2016-44, 2016

Manuscript under review for journal Hydrol. Earth Syst. Sci.

Published: 18 February 2016

(c) Author(s) 2016. CC-BY 3.0 License.

2. Alansi A.W., Amin, M.S.M., Halim, G.A., Shafri, H.Z.M., and Aimrun, W.: Validation of SWAT model for stream flow simulation and forecasting in Upper Bernam humid tropical river basin, Malaysia. Hydrol. Earth Syst. Sci. Discuss., 6, 7581-7609, 2009.

3. Arabi, M., Govindaraju, R.S., Hantush, M.M., and Engel, B.A.: Role of watershed subdivision on modeling the effectiveness of best management practice with SWAT. JAWRA Journal of the American Water Resources Association, 42, 513-528, 2006.

4. Arnold, J. G., and Allen, P. M.: Estimating hydrologic budgets for three Illinois watersheds. Journal of Hydrology, 176, 57-77, 1996.

5. Arnold, J.G., and Allen, P.M.: Automated methods for estimating baseflow and ground water recharge from streamflow records. Journal of the American Water Resources Association 35(2): 411-424, 1999.

6. Arnold, J.G., Srinivasan, R., Muttiah, R.S., and Williams, J.R.: Large area hydrologic modeling and assessmentPart 1: model development. Journal of American Water Resources Association, 34, pp. 73-89, 1998.

7. Ba'rdossy, A.: Calibration of hydrological model parameters for ungauged catchments. Hydrol. Earth Syst. Sci., 11, 703-710, 2007.

8. Bastola, S., Ishidaira, H., and Takeuchi, K.: Regionalization of hydrological model parameters under parameter uncertainty: A case study involving TOPMODEL and basins across the globe. Journal of Hydrology, 357(3-4), 188-206, 2008.

9. Cerda' A.: Effect of climate on surface flow along a climatological gradient. A field rainfall simulation approach. $\mathbf{J}$ Arid Environ 38:145-159, 1998.

10. Chow, V.T., Maidment, D.R., and Mays, L.W.: Applied hydrology. McGraw-Hill, Inc., New York, NY,1988.

11. El Kateb, H., Zhang, H., Zhang, P., and Mosandl. R.: Soil erosion and surface runoff on different vegetation covers and slope gradients: A field experiment in Southern Shaanxi Province, China. CATENA, Volume 105, June 2013, Pages 1-10, 2013.

12. Food and Agriculture Organization of the United Nations (FAO): The digital soil map of the world and derived soil properties, version 3.6, Rome, 2003.

13. Faramarzi, M., Abbaspour, K. C., Schulin, R., and Yang, H.: Modelling blue and green water resources availability in Iran. Hydrological Processes, 23, 486-501, 2009.

14. Immerzeel, W. W., Droogers, P.: Calibration of a distributed hydrological model based on satellite evapotranspiration. Journal of Hydrology, 349, 411-424. 2008.

15. Kokkonen, T., Jakeman, A., Young, P., and Koivusalo, H.: Predicting daily flows in ungauged catchments: model regionalization from catchment descriptors at the Coweeta Hydrologic Laboratory, North Carolina., Hydrol. Processes, 11, 2219-2238, 2003.

16. Labrière, N., Locatelli, B., Laumonier, Y., Freycon, V., and Bernoux, M.: Soil erosion in the humid tropics: A systematic quantitative review. Agriculture, Ecosystems \& Environment, 203, 127-139, 2015. 
Hydrol. Earth Syst. Sci. Discuss., doi:10.5194/hess-2016-44, 2016

Manuscript under review for journal Hydrol. Earth Syst. Sci.

Published: 18 February 2016

(c) Author(s) 2016. CC-BY 3.0 License.

17. McIntyre, N., Lee, H., Wheater, H., Young, A., and Wagener, T.: Ensemble predictions of runoff in ungauged catchments, Water Resour. Res., 41(12),W12434, doi:10.1029/2005WR004289,2005, 2005.

18. Meaurio, M., Zabaleta, A., Uriarte, J. A., Srinivasan, R., and Antigüedad, I.: Evaluation of SWAT models performance to simulate streamflow spatial origin. The case of a small forested watershed. Journal of Hydrology, 525, 326-334, 2015.

19. Merz, R., and Blöschla G.: Regionalisation of catchment model parameters. Journal of Hydrology 287(1-4), 95123, 2004.

20. Moriasi, D. N., Arnold, J. G., Van Liew, M. W., Bringer, R. L., Harmel, R. D., and Veith, T. L.: Model evaluation guidelines for systematic quantification of accuracy in watershed simulations. Am. Soc. Agric. Biol. Eng., 50 (3), 885-900, 2007.

21. Mu, Q., Zhao M., and Running S. W., Improvements to a MODIS Global Terrestrial Evapotranspiration Algorithm, Remote Sensing of Environment, 115, 1781-1800, 2011.

22. Neitsch, S.L., Arnold, J.G., Kiniry, J.R., Williams, J.R., and King, K.W.: Soil and water assessment tool. Theoretical documentation. TWRI TR-191. College Station, Texas: Texas Water Resources Institute, 2011.

23. Nguyen A. H.: Comprehensively studying geographical arising and land degradation aiming the purpose of reasonably using land resource and preventing disaster in Binh - Tri - Thien region. Doctor of Philosophy Dissertation. Hanoi, 2010.

24. Nguyen, H. Q., and Kappas, M.: Modeling Surface Runoff and Evapotranspiration using SWAT and BEACH for a Tropical Watershed in North Vietnam, Compared to MODIS Products. International Journal of Advanced Remote Sensing and GIS, 4, 1367-1384, 2015.

25. Parajka, J., Merz, R., and Bloschl, G.: A comparison of regionalization methods for catchment model parameters., Hydrol. Earth Syst. Sci., 9, 157-171, 2005.

26. Petković, D., Gocic, M., Trajkovic, S., Shamshirband, S., Motamedi, S., Hashim, R.,and Bonakdari, H.: Determination of the Most Influential Weather Parameters on Reference Evapotranspiration by Adaptive NeuroFuzzy Methodology. Computers and Electronics in Agriculture. 2015. 114; 277-284, 2015.

27. Perrin, J., Ferrant, S., Massuel, S., Dewandel, B., and Maréchal, J. C., Aulong, S., Ahmed, S.: Assessing water availability in a semi-arid watershed of southern India using a semi-distributed model. Journal of Hydrology, 460461, 143-155, 2012.

28. Phuong, T. T., and Chuong, H. V.: Simulating effects of land use change on soil erosion in Bo River basin in the Central of Vietnam. Journal of Agriculture and Rural Development, Vol 2 - October, 2013.

29. Phuong, T. T., Thong, C. V. T., Ngoc, N. B, Chuong, H. V.: Modeling Soil Erosion within Small Moutainous Watershed in Central Vietnam Using GIS and SWAT. Resources and Environment, 4, 139-147, 2014.

30. Rafiei Emam, A., Kappas, M., and Abbaspour, K.C.: Simulation of water balance components in a watershed located in central drainage basin of Iran. In: Remote Sensing of the Terrestrial Water Cycle, Geophysical 
Hydrol. Earth Syst. Sci. Discuss., doi:10.5194/hess-2016-44, 2016

Manuscript under review for journal Hydrol. Earth Syst. Sci.

Published: 18 February 2016

(c) Author(s) 2016. CC-BY 3.0 License.

Monograph 206 (V. Lakshmi, ed.). American Geophysical Union. Wiley \& Sons press. ISBN: 9781118872031 , 2015a.

31. Rafiei Emam, A., Kappas, M., Akhavan, S., Hosseini, S.Z., and Abbaspour, K.C. Estimation of groundwater recharge and its relation to land degradation: Case study of a semi-arid river basin in Iran. Environmental earth sciences journal, 74, 6791-6803. doi: 10.1007/s12665-015-4674-2, $2015 \mathrm{~b}$.

32. Rafiei Emam, A., Kappas, M., and Hosseini, S.Z.: Assessing the impact of climate change on water resources, crop production and land degradation in a semi-arid river basin. Hydrology Research 46.6, 854-870, $2015 \mathrm{c}$.

33. Ritchie, J. T.: A model for predicting evaporation from a row crop with incomplete cover. Water Resour. Res. 8, 1204-1213, 1972.

34. Samaniego, L. and B'ardossy, A.: Robust parametric models of runoff characteristics at the mesoscale, J. Hydrol., 303, 136-151, 2005.

35. Santhi, C., Arnold, J. G., Williams, J. R., Dugas, W. A., Srinivasan, R. and Hauck, L. M.: Validation of the SWAT model on a large river basin with point and nonpoint sources. J. Am.Water Resour. Assoc. 37 (5), 1169-1188, 2001.

36. Sheshukov, A. Y., Douglas-Mankin, K. R., Sinnathamby, S., and Daggupati, P.: Pasture BMP effectiveness using an HRU-based subarea approach in SWAT. Journal of environmental management, 166, 276-284, 2016.

37. Soil Survey Staff: Keys to Soil Taxonomy, 12th ed. USDA-Natural Resources Conservation Service, Washington, DC, 2014.

38. Smith, C. M., Nejadhashemi, A. P., Leatherman, J. C.: Using a BMP Auction as a Tool for the Implementation of Conservation Practices. Journal of extension, 47.2009

39. Stewart, M., Cimino, J., and Ross, M.: Calibration of Base Flow Separation Methods with Streamflow Conductivity. Ground Water, 45, 17-27, 2007.

40. Schuol, J., Abbaspour, K. C., Yang, H., Srinivasan, R., Zehnder, A.J.B.: Modeling blue and green water availability in Africa. Water Resources Research 44, 1-18, 2008.

41. Sun, W.C., Ishidaira, H., and Bastola, S.: Towards improving river discharge estimation in ungauged basins: calibration of rainfall-runoff models based on satellite observations of river flow width at basin outlet.Hydrology and Earth System Science 14: 2011-2022. DOI: 10.5194/hess-14-2011-2010., 2010.

42. Sun, W.C., Ishidaira, H., and Bastola, S.: Calibration of hydrological models in ungauged basins based on satellite radar altimetry observations of river water level. Hydrol. Process. 26, 3524-3537, 2012.

43. USDA: United States Department of Agriculture. Urban hydrology for small watersheds. Technical Release 55 30 (TR-55) (Second ed.). Natural Resources Conservation Service, Conservation Engineering Division, 1986.

44. Vandewiele, G.L., and Atlabachew E.: Monthly water balance of ungauged catchments obtained by geographical regionalization. Journal of Hydrology, 170, 277-229 271, 1995. 
Hydrol. Earth Syst. Sci. Discuss., doi:10.5194/hess-2016-44, 2016

Manuscript under review for journal Hydrol. Earth Syst. Sci.

Published: 18 February 2016

(c) Author(s) 2016. CC-BY 3.0 License.

(c) (i)

45. Vilaysane, B., Takara, K., Luo, P., Akkharath, I., and Duan, W.: Hydrological Stream Flow Modelling for Calibration and Uncertainty Analysis Using SWAT Model in the Xedone River Basin, Lao PDR. Procedia Environmental Sciences, 28, 380-390, 2015.

46. Williams, J.R.: Sediment Yield Prediction with Universal Equation using Runoff Energy Factor, ARS-S40.Agricultural Research Service, Washington, DC., 1975.

47. Wischmeier, W.H., and Smith, D.D.: Predicting rainfall-erosion losses from cropland east of the Rocky Mountains. Agr. Handbook No.282, U.S.Dept.Agr.,Washington, DC., 1965.

48. Xu, X. Y., Yang, H. B., Yang, D. W. and Ma, H.: Assessing the impact of climate variability and human activities on annual runoff in the Luan River basin, China. Hydrol. Res. 44 (5), 940-952. 2013. 
Hydrol. Earth Syst. Sci. Discuss., doi:10.5194/hess-2016-44, 2016

Manuscript under review for journal Hydrol. Earth Syst. Sci.

Published: 18 February 2016

(c) Author(s) 2016. CC-BY 3.0 License.

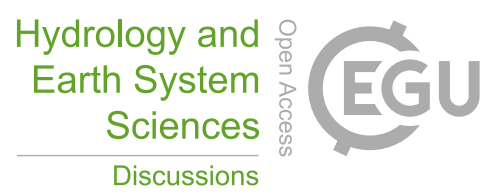

(c) (1)

Table 1. Properties of the donor and target catchments

\begin{tabular}{|c|c|c|c|c|c|c|c|}
\hline Catchment & River & $\begin{array}{l}\text { Rain } \\
\text { gauge } \\
\text { station }\end{array}$ & $\begin{array}{l}\text { Rainfall } \\
\mathrm{mm}\end{array}$ & $\begin{array}{l}\text { Area } \\
\mathrm{Km}^{2}\end{array}$ & $\begin{array}{l}\text { Slope } \\
\text { (Mean) } \\
\%\end{array}$ & $\begin{array}{l}\text { Elevation } \\
\text { (Mean) } \\
\mathrm{m}\end{array}$ & L/W* \\
\hline Aluoi & Song Sia River & Aluoi & 3900 & 408 & 38 & 495 & 1.90 \\
\hline Thuong Nhat & Ta Trach River & Nam Dong & 3800 & 125 & 42 & 490 & 1.05 \\
\hline
\end{tabular}

*L/W: Length/Width 
Hydrol. Earth Syst. Sci. Discuss., doi:10.5194/hess-2016-44, 2016

Manuscript under review for journal Hydrol. Earth Syst. Sci.

Published: 18 February 2016

(c) Author(s) 2016. CC-BY 3.0 License.

Table 2. SWAT parameters and their initial and final range for river discharge and ETa calibration

\begin{tabular}{|c|c|c|c|c|c|}
\hline ID & Parameters* & Description & $\begin{array}{l}\text { Initial } \\
\text { range }\end{array}$ & Final range & Description \\
\hline 1 & $\mathrm{r} \_\mathrm{CN} 2 . \mathrm{mgt}$ & Curve number & -0.5 to 0.5 & 0.10 to 0.5 & \multirow{14}{*}{ 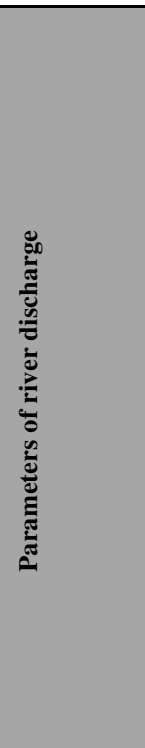 } \\
\hline 2 & r__SOL_BD().sol & Soil bulk density & -0.5 to 0.5 & 0.1 to 0.32 & \\
\hline 3 & r__SOL_K().sol & Soil conductivity (mm/hr) & -0.5 to 0.5 & $\begin{array}{l}-0.30 \text { to }- \\
0.02\end{array}$ & \\
\hline 4 & r__SOL_AWC().sol & $\begin{array}{l}\text { Soil available water storage } \\
\text { capacity (mm H2O/mm soil) }\end{array}$ & -0.5 to 0.5 & $\begin{array}{l}-0.85 \text { to }- \\
0.47\end{array}$ & \\
\hline 5 & v_CH_K2.rte & $\begin{array}{l}\text { Effective hydraulic } \\
\text { conductivity in main channel }\end{array}$ & 50 to 400 & 300 to 400 & \\
\hline 6 & v_ALPHA_BNK.rte & $\begin{array}{l}\text { Base flow alpha factor for } \\
\text { bank storage }\end{array}$ & 0 to 1 & 0.35 to 0.59 & \\
\hline 7 & r__CH_N2.rte & $\begin{array}{l}\text { Manning value for main } \\
\text { channel }\end{array}$ & -0.5 to 0.5 & 0.51 to 0.75 & \\
\hline 8 & r__OV_N.hru & $\begin{array}{l}\text { Manning value for overland } \\
\text { channel }\end{array}$ & -0.5 to 0.5 & $\begin{array}{l}-0.42 \text { to }- \\
0.06\end{array}$ & \\
\hline 9 & r__SLSUBBSN.hru & Average slope length (m) & -0.5 to 0.5 & 0.56 to 0.90 & \\
\hline 10 & v_GWQMN.gw & $\begin{array}{l}\text { Threshold water level in } \\
\text { shallow aquifer for base flow }\end{array}$ & 100 to 5000 & 3133 to 3756 & \\
\hline 11 & v_GW_DELAY.gw & $\begin{array}{l}\text { Ground water delay time } \\
\text { (days) }\end{array}$ & 10 to 500 & 185 to 240 & \\
\hline 12 & v_ALPHA_BF.gw & Base flow alpha factor (days) & 0.04 to 0.07 & 0.047 to 0.065 & \\
\hline 13 & v_GW_REVAP.gw & Revap coefficient & 0.02 to 0.2 & 0.04 to 0.07 & \\
\hline 14 & v__REVAPMN.gw & $\begin{array}{l}\text { Threshold water level in } \\
\text { shallow aquifer }\end{array}$ & 0 to 500 & 155 to 195 & \\
\hline 15 & v_ESCO.hru & $\begin{array}{l}\text { Soil evaporation } \\
\text { compensation factor }\end{array}$ & 0.1 to 1.0 & 0.40 to 0.65 & \multirow{5}{*}{ 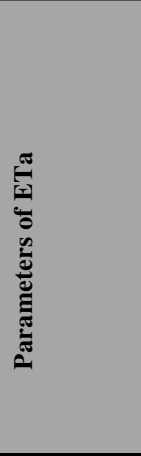 } \\
\hline 16 & $v_{\text {___WAVP }}\{8\}$.plant.dat & $\begin{array}{l}\text { Rate of decline in radiation } \\
\text { use efficiency per unit } \\
\text { increase in vapor pressure } \\
\text { deficit. }\end{array}$ & 1 to 50 & 43 to 46 & \\
\hline 17 & V__DLAI $\{8\}$.plant.dat___FRST & $\begin{array}{l}\text { Fraction of growing season } \\
\text { when leaf area begins to } \\
\text { decline in forest area }\end{array}$ & 0.15 to 1 & 0.95 to 0.99 & \\
\hline 18 & V_BLAI $\{8\}$.plant.dat___ FRST & $\begin{array}{l}\text { Maximum potential leaf area } \\
\text { index of forest areas }\end{array}$ & 2 to 10 & 2.7 to 5.7 & \\
\hline 19 & v_HEAT_UNITS $\{[], 1\} . \mathrm{mgt}$ & $\begin{array}{l}\text { Total heat units for plant to } \\
\text { reach maturity in forest areas }\end{array}$ & $\begin{array}{l}1000 \text { to } \\
4500\end{array}$ & 2900 to 3350 & \\
\hline
\end{tabular}

$*_{\mathrm{r}}$ parameter value is multiplied by $1+$ given value, $\mathrm{v}$ parameter value is replaced by a value from the given range 
Hydrol. Earth Syst. Sci. Discuss., doi:10.5194/hess-2016-44, 2016

Manuscript under review for journal Hydrol. Earth Syst. Sci.

Published: 18 February 2016

(c) Author(s) 2016. CC-BY 3.0 License.

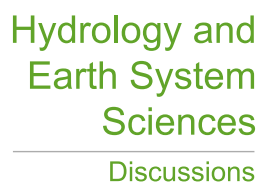

(c) (i)

Table 3. The average water components (2006-2013) in HRUs in dry farmlands with slope larger than $25 \%$

\begin{tabular}{|c|c|c|c|c|c|c|}
\hline BMP & $\begin{array}{l}\text { Surface } \\
\text { runoff } \\
(\mathrm{mm})\end{array}$ & $\begin{array}{l}\text { Percolation } \\
(\mathrm{mm})\end{array}$ & $\begin{array}{l}\text { Soil } \\
\text { content } \\
(\mathrm{mm})\end{array}$ & water & $\begin{array}{l}\text { Eta } \\
(\mathbf{m m})\end{array}$ & $\begin{array}{l}\text { Total sediment } \\
\text { (ton/ha) }\end{array}$ \\
\hline No application & 290 & 0.5 & 20 & & 30 & 112 \\
\hline Terracing & 200 & 17 & 49 & & 41 & 50 \\
\hline Contouring & 140 & 29 & 68 & & 48 & 32 \\
\hline
\end{tabular}


Hydrol. Earth Syst. Sci. Discuss., doi:10.5194/hess-2016-44, 2016

Manuscript under review for journal Hydrol. Earth Syst. Sci.

Published: 18 February 2016

FIGURES

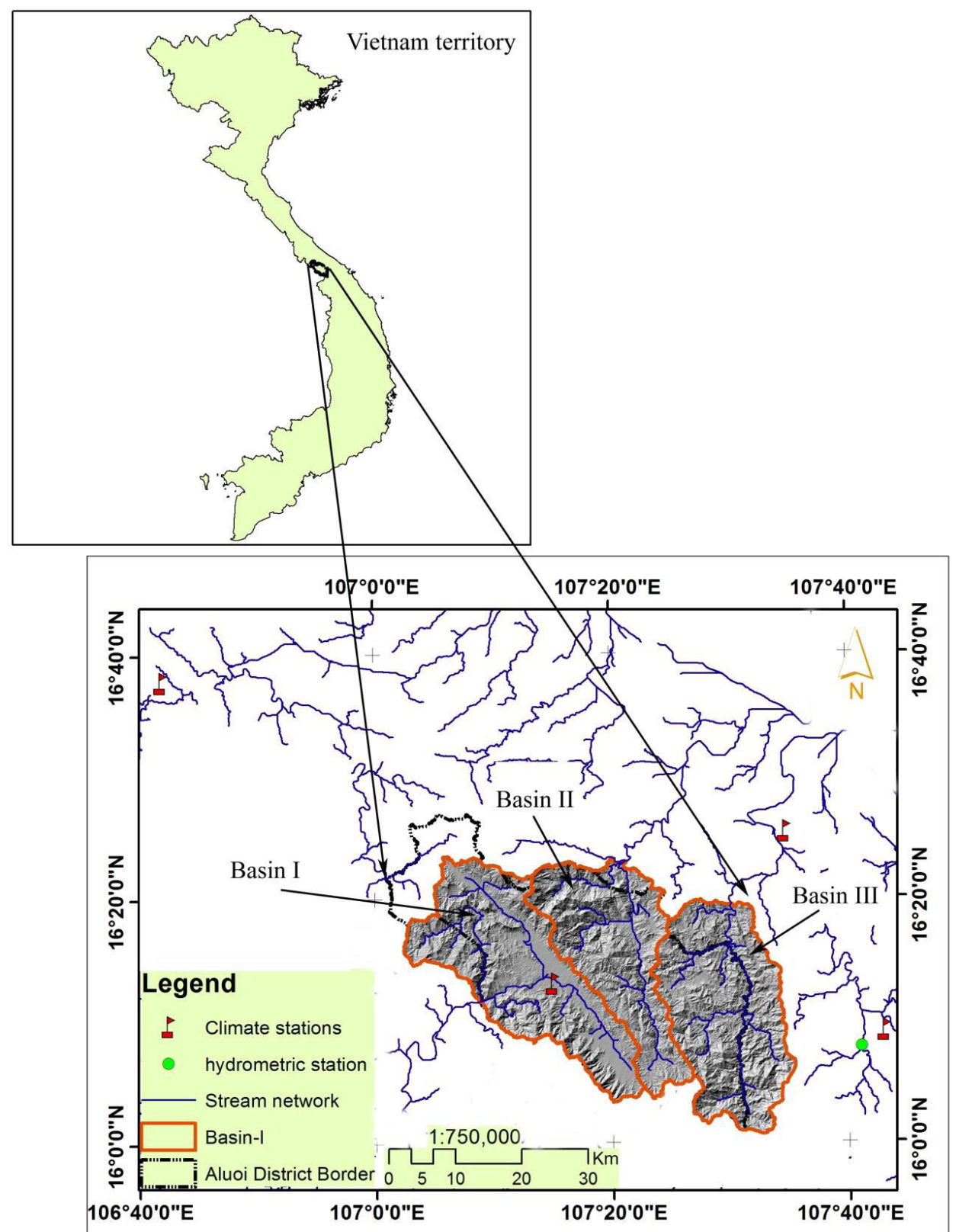

Figure 1. Study area showing stream networks, climate and hydrometric stations and the Aluoi district border. The Aluoi district consists of three basins, which are shown in this figure. 
Hydrol. Earth Syst. Sci. Discuss., doi:10.5194/hess-2016-44, 2016

Manuscript under review for journal Hydrol. Earth Syst. Sci.

Published: 18 February 2016

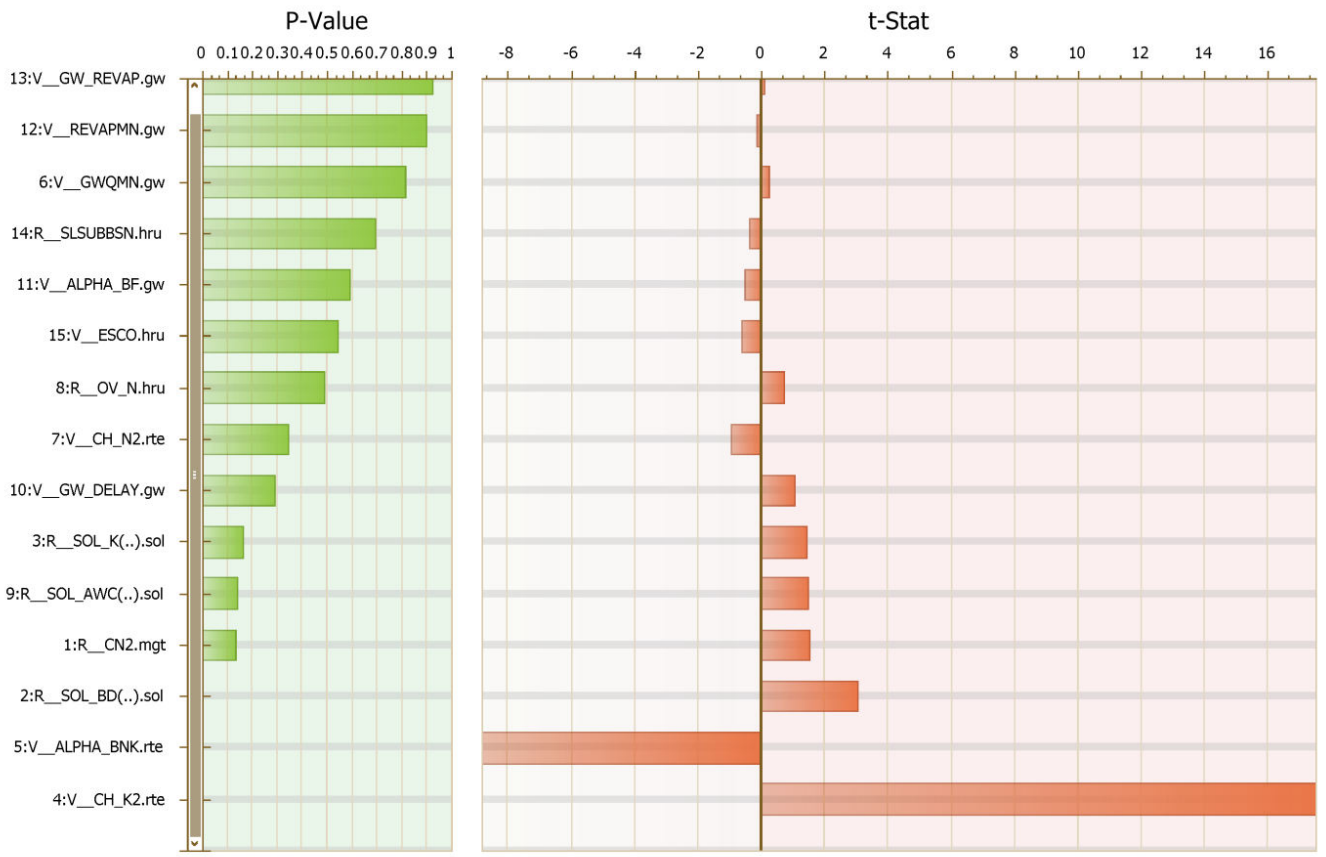

Figure 2. Sensitivity analysis of parameters for river discharge calibration, P-value shows the measure of sensitivity, the larger $t$-values are more sensitive. $t$-test represents the significance of sensitivity, the smaller the $p$-value, the less chance of a parameter being by chance assigned as sensitive. 
Hydrol. Earth Syst. Sci. Discuss., doi:10.5194/hess-2016-44, 2016

Hydrology and Manuscript under review for journal Hydrol. Earth Syst. Sci.

Published: 18 February 2016

(c) Author(s) 2016. CC-BY 3.0 License.
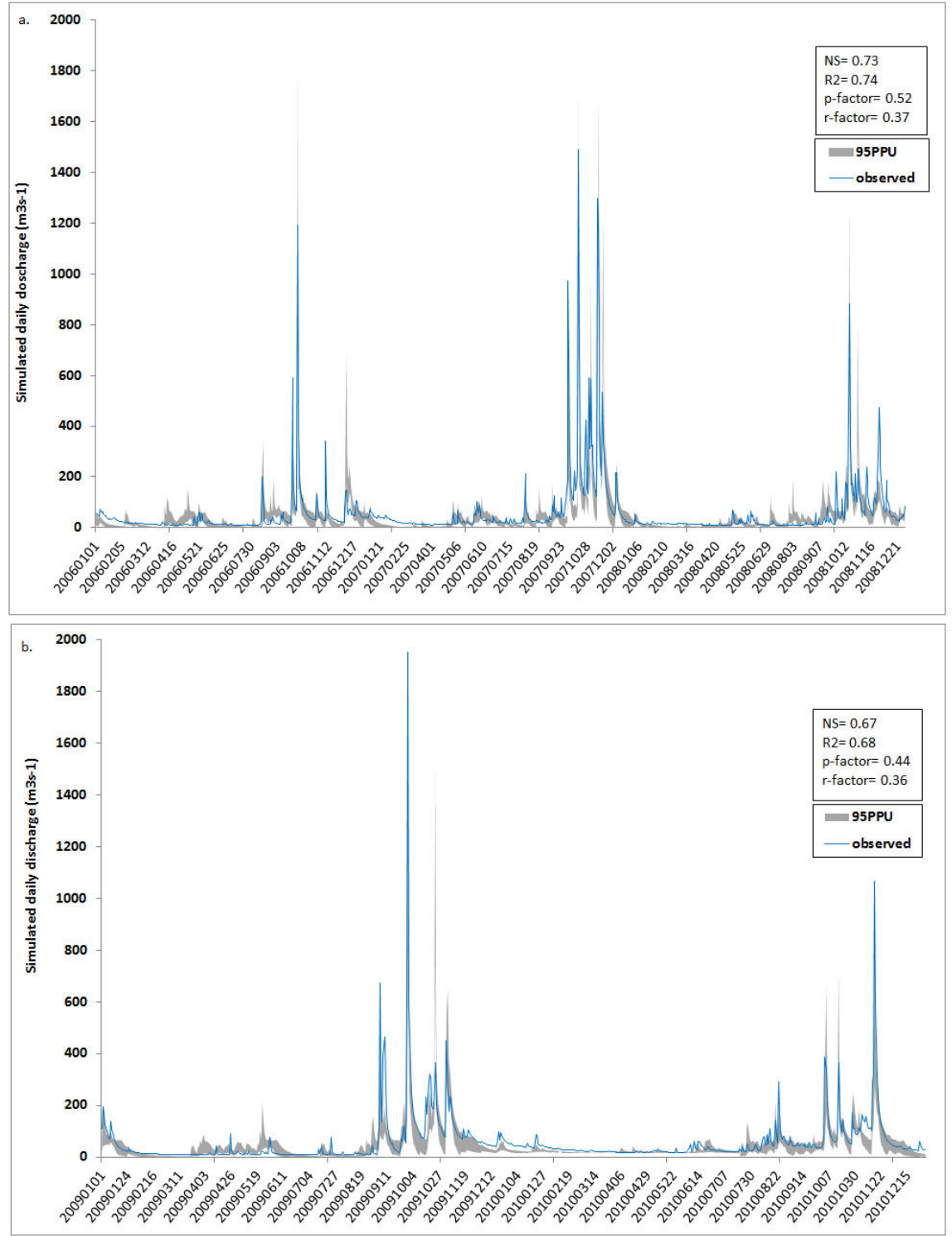

Figure 3. Calibration and validation of the model by river discharge data 
Hydrol. Earth Syst. Sci. Discuss., doi:10.5194/hess-2016-44, 2016

Manuscript under review for journal Hydrol. Earth Syst. Sci.

Published: 18 February 2016

(c) Author(s) 2016. CC-BY 3.0 License.
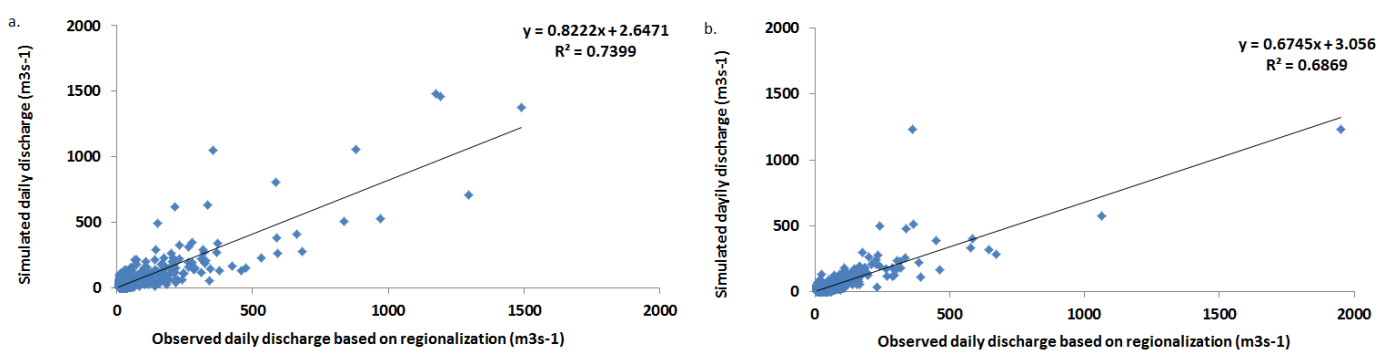

Figure 4. Scatter plot of daily river discharge for calibration a) from $1 / 1 / 2006$ to $31 / 12 / 2008$ and b) the validation period from $1 / 1 / 2009$ to $31 / 12 / 2010$ 
Hydrol. Earth Syst. Sci. Discuss., doi:10.5194/hess-2016-44, 2016

Hydrology and Manuscript under review for journal Hydrol. Earth Syst. Sci.

Published: 18 February 2016

(c) Author(s) 2016. CC-BY 3.0 License.

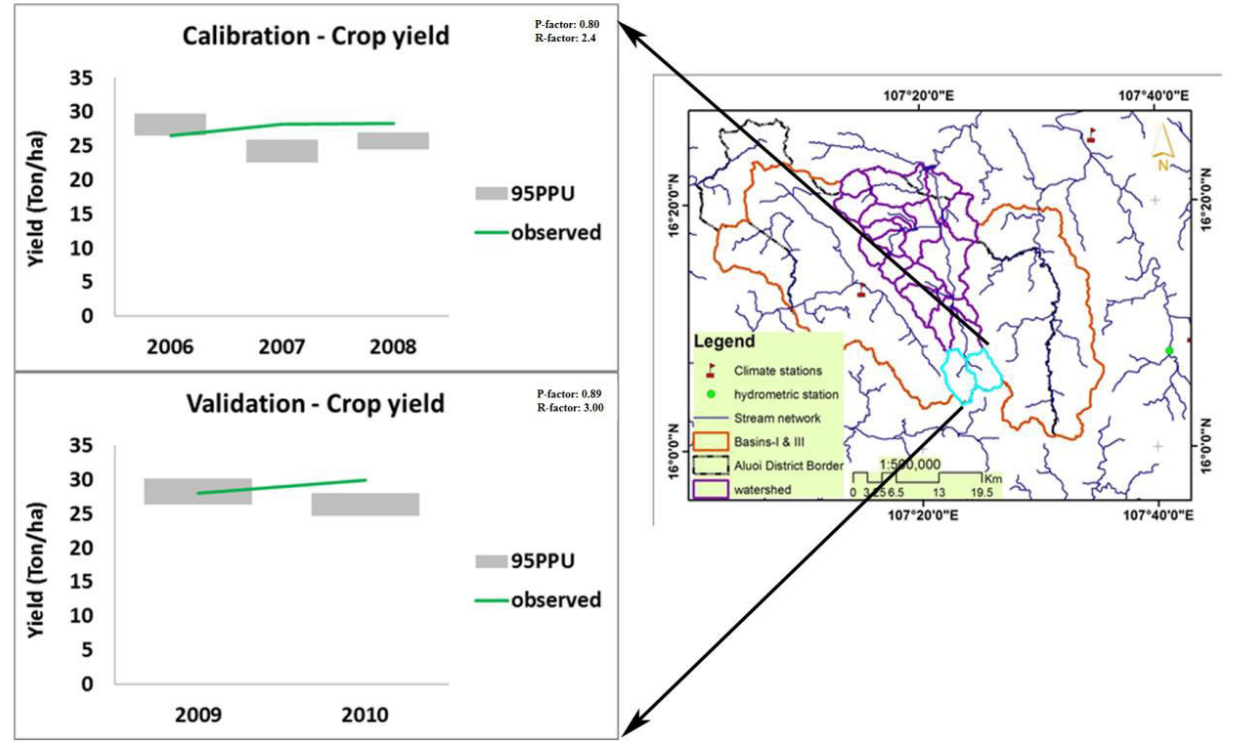

Figure 5. Calibration and Validation of model for crop yield (rice) 
Hydrol. Earth Syst. Sci. Discuss., doi:10.5194/hess-2016-44, 2016

Hydrology and Manuscript under review for journal Hydrol. Earth Syst. Sci.

Published: 18 February 2016

(c) Author(s) 2016. CC-BY 3.0 License.

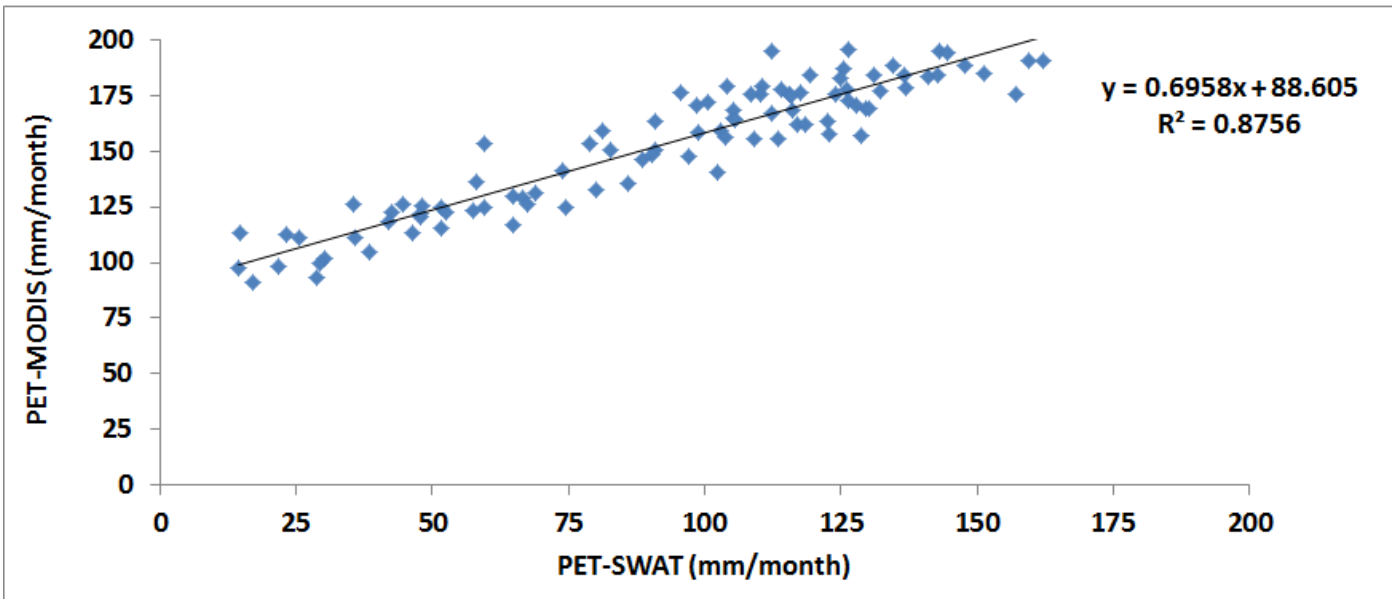

Figure 6. Correlation between ETP of MODIS products and SWAT 
Hydrol. Earth Syst. Sci. Discuss., doi:10.5194/hess-2016-44, 2016

Manuscript under review for journal Hydrol. Earth Syst. Sci.

Published: 18 February 2016

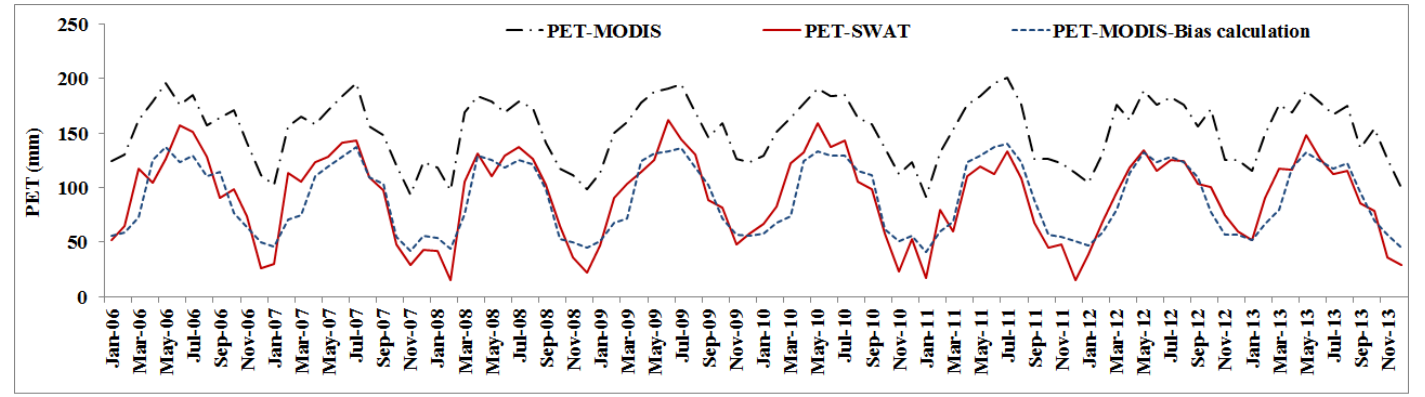

Figure 7 Comparing ETP extracted from MODIS-MOD16 with one measured using the Penman-Monthieh method. For bias correction, MODIS data were multiplied by 0.45 for the period of October-March and 0.70 for AprilSeptember 
Hydrol. Earth Syst. Sci. Discuss., doi:10.5194/hess-2016-44, 2016 Manuscript under review for journal Hydrol. Earth Syst. Sci.

Published: 18 February 2016

(c) Author(s) 2016. CC-BY 3.0 License.
Hydrology and Earth System Sciences

Discussions
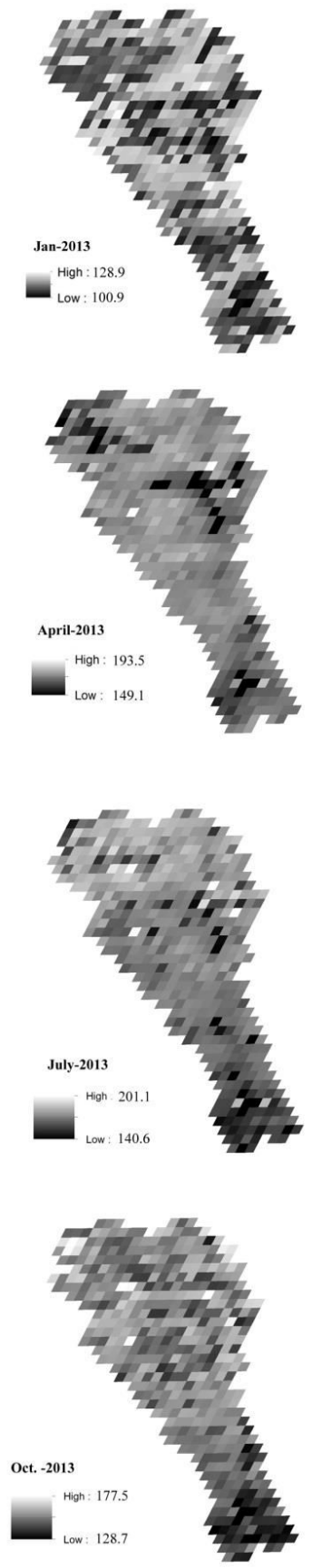
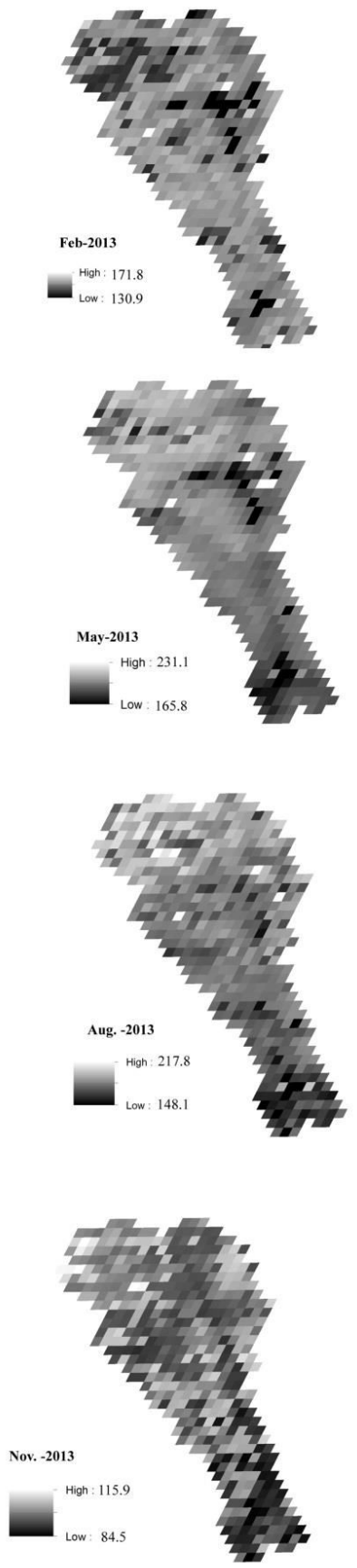
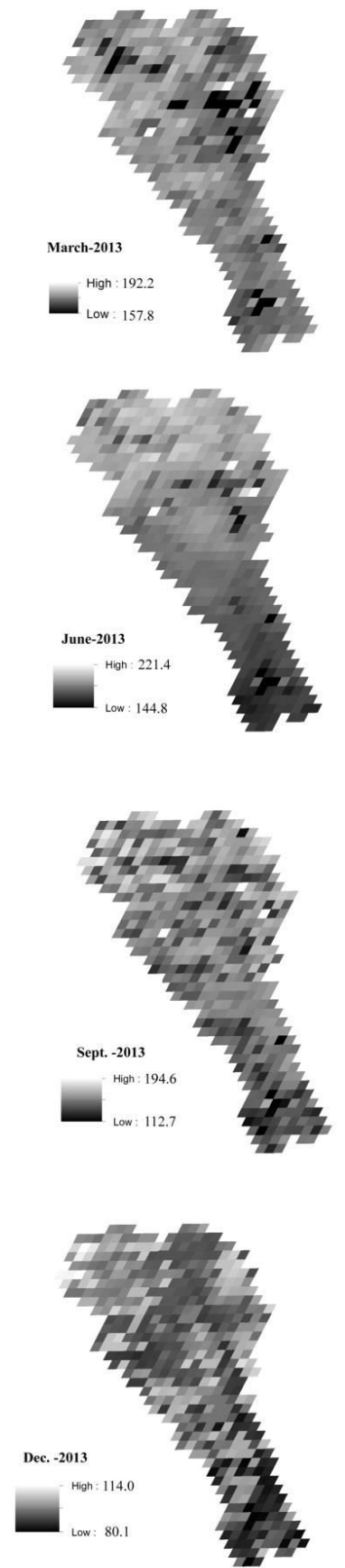

Figure 8. Anomaly maps of ETP extracted from MODIS-MOD16 from January to December 2013 after bias correction 
Hydrol. Earth Syst. Sci. Discuss., doi:10.5194/hess-2016-44, 2016

Manuscript under review for journal Hydrol. Earth Syst. Sci.

Published: 18 February 2016

(c) Author(s) 2016. CC-BY 3.0 License.

a.

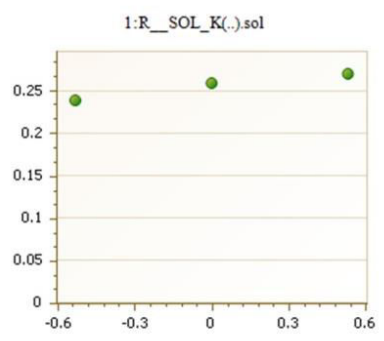

b.

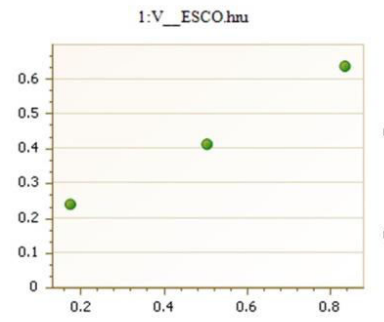

1:R_SOL_AWC(..).sol

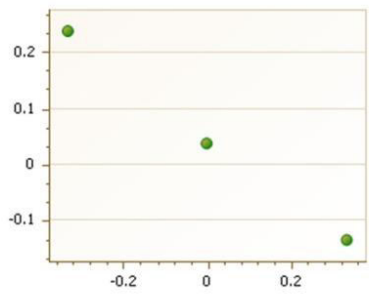

1:V_HEAT_UNITS $\{..\} \mathrm{mg}$

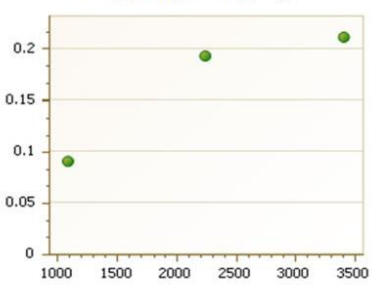

1:R_SOL_BD(...).sol
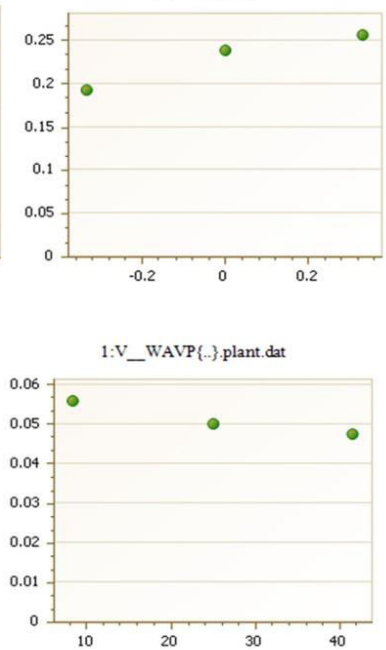

Figure 9. Dotty plot of sensitive parameters versus objective function (Nash Sutcliffe) based on the one-at-a-time method, showing the sensitivity of parameters of model for a) river discharge calibration and b) ET calibration. In this figure, Parameter SOL-AWC is the most sensitive parameter to calibrate river discharge, and the ESCO parameter and heat unit are more sensitive than other parameters. The $\mathrm{x}$-axis shows the value of parameters, or relative changes, and the y-axis shows the objective function value. The higher the value of the objective function, the better the value for parameters. For instance, the best fitting values for SOL-AWC are less than zero in relative change ( $r_{-}$), meaning that the initial value should decrease more than $20 \%$. It is important to note that the one-at-atime sensitivity analysis is applied for only one parameter at a time. 
Hydrol. Earth Syst. Sci. Discuss., doi:10.5194/hess-2016-44, 2016

Manuscript under review for journal Hydrol. Earth Syst. Sci.

Published: 18 February 2016

(c) Author(s) 2016. CC-BY 3.0 License.

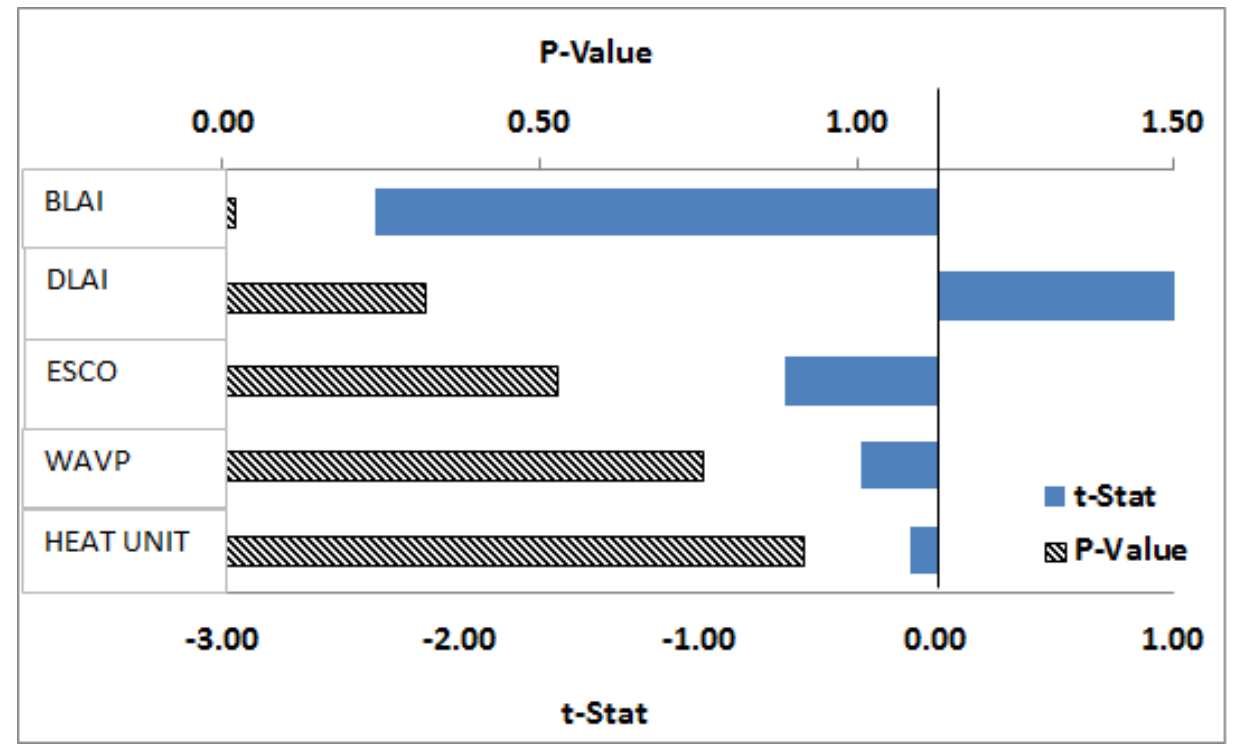

Figure 10. Global sensitivity analysis, showing the measure of sensitivity (T-value) and the significant of sensitivity (P-value). The graphs reveal that BLAI followed by DLAI are the most sensitive parameters for ETa calibration. 
Hydrol. Earth Syst. Sci. Discuss., doi:10.5194/hess-2016-44, 2016

Manuscript under review for journal Hydrol. Earth Syst. Sci.

Published: 18 February 2016

(c) Author(s) 2016. CC-BY 3.0 License.

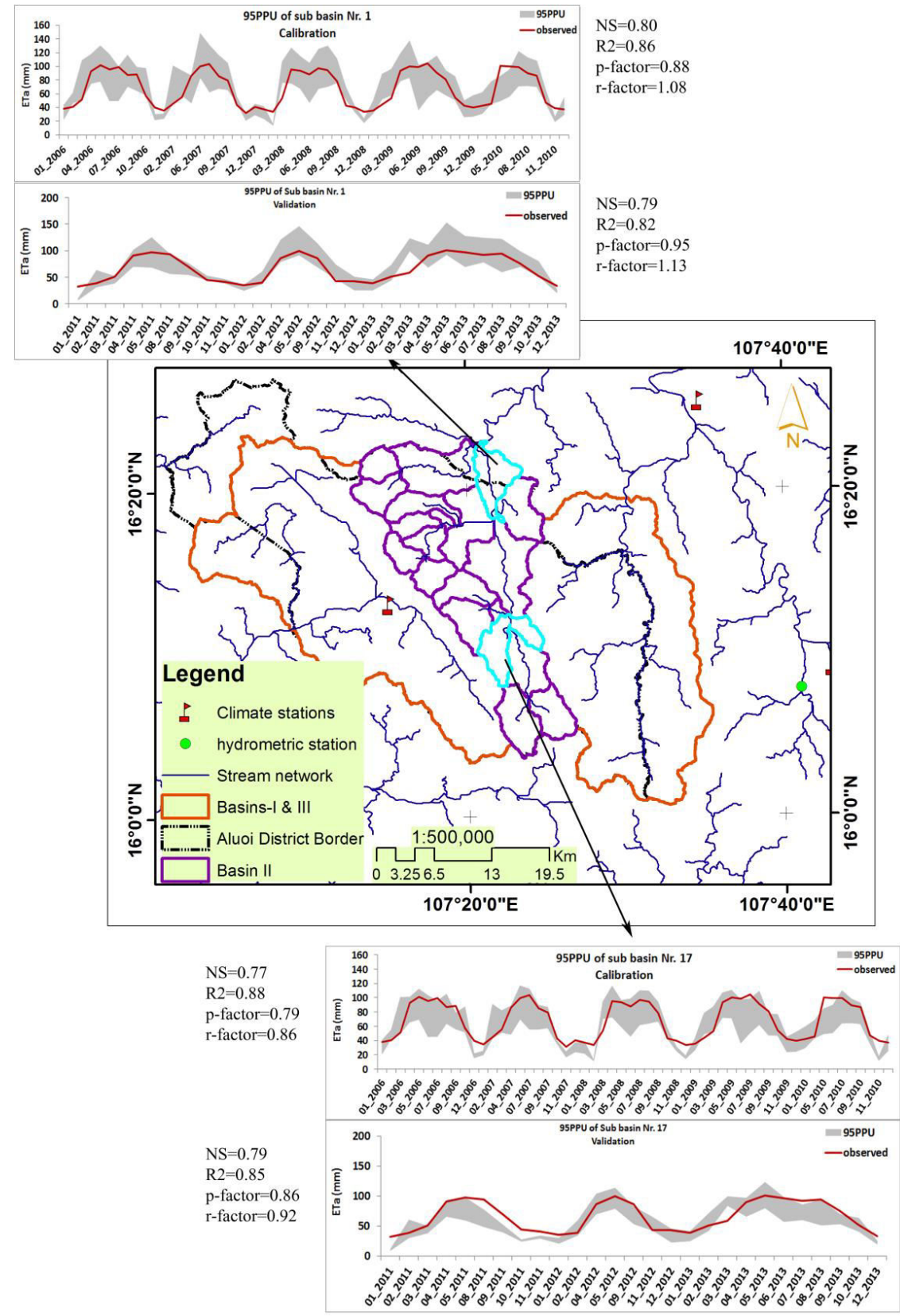

Figure 11. Results of calibration of ETa using MODIS data north and south of Basin-II. P-factor and r-factors show the strength of calibration and uncertainty performance, in which p-factor is the percentage of observed data bracketed by 95PPU, and r-factor is the average width of 95PPU band divided by the standard deviation of measured data. 95PPU (95 Percent Prediction Uncertainty) shows the lower and higher ET's prediction values in 500 times iterations of calibration procedure. NS refers to the Nash-Sutcliffe coefficient and $r^{2}$ means coefficient of determination. 
Hydrol. Earth Syst. Sci. Discuss., doi:10.5194/hess-2016-44, 2016

Manuscript under review for journal Hydrol. Earth Syst. Sci.

Published: 18 February 2016

(c) Author(s) 2016. CC-BY 3.0 License.
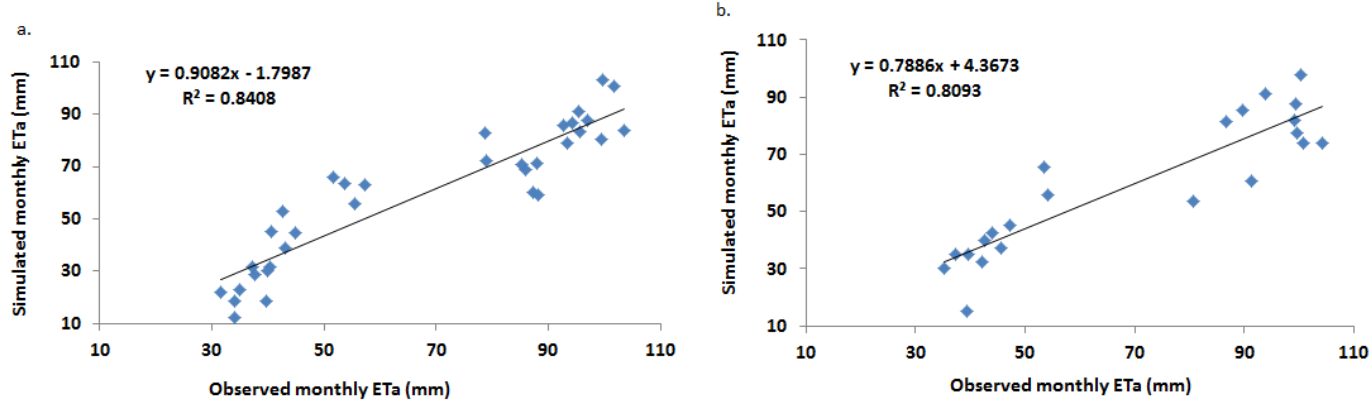

Figure 12. The relationship between monthly ET of SWAT model and MODIS data during calibration a) from $1 / 1 / 2006$ to $31 / 12 / 2008$ and $b$ ) the validation period from $1 / 1 / 2008$ to $31 / 12 / 2010$. 
Hydrol. Earth Syst. Sci. Discuss., doi:10.5194/hess-2016-44, 2016

Manuscript under review for journal Hydrol. Earth Syst. Sci.
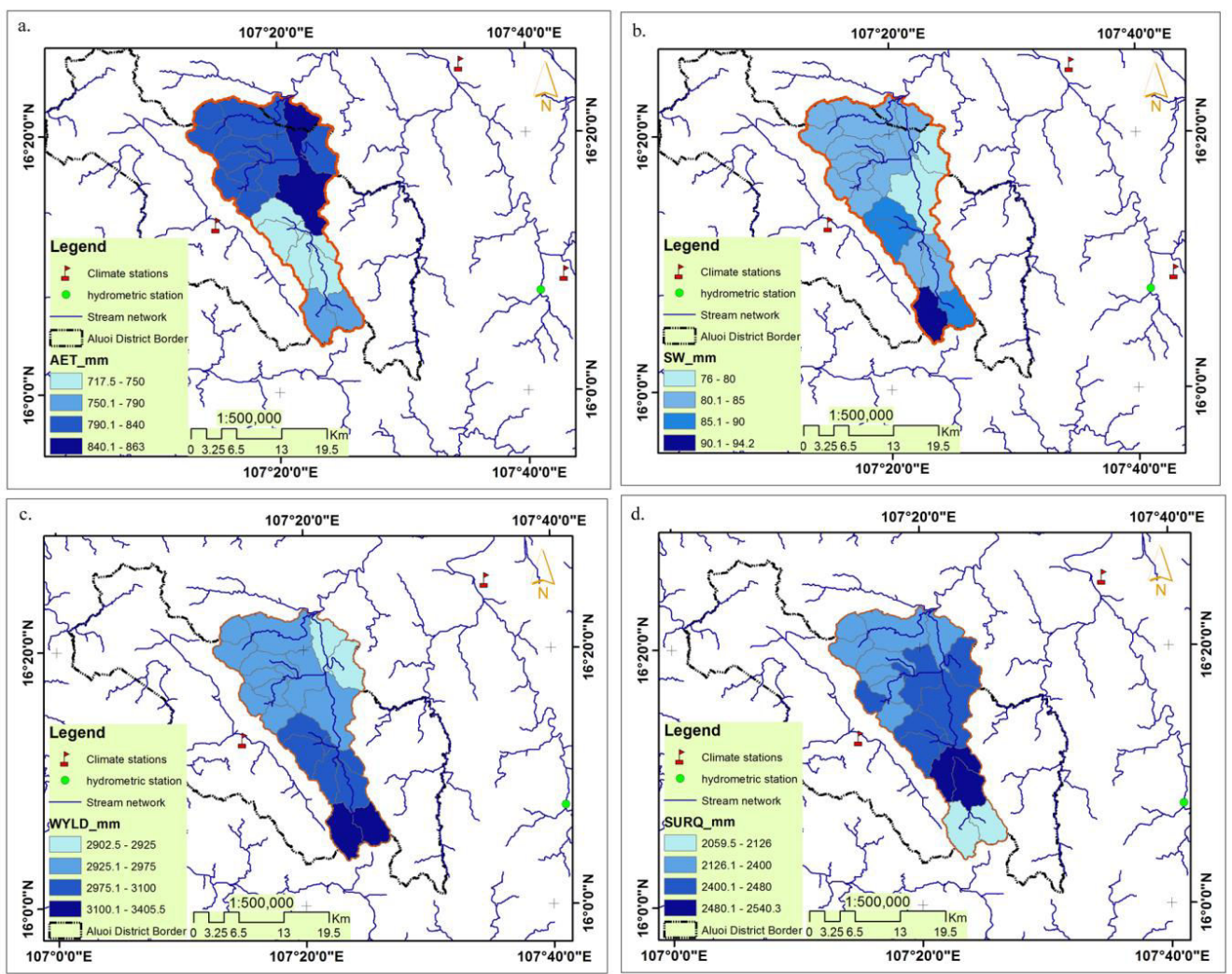

Figure 13. Spatial pattern of hydrological components in Aluoi area: a) the distribution of average annual (20052013) actual evapotranpiration (AET); b) soil water content (SW); c) water yield (WYLD); and d) surface runoff (SURQ). 
Hydrol. Earth Syst. Sci. Discuss., doi:10.5194/hess-2016-44, 2016

Manuscript under review for journal Hydrol. Earth Syst. Sci.

Published: 18 February 2016

(c) Author(s) 2016. CC-BY 3.0 License.

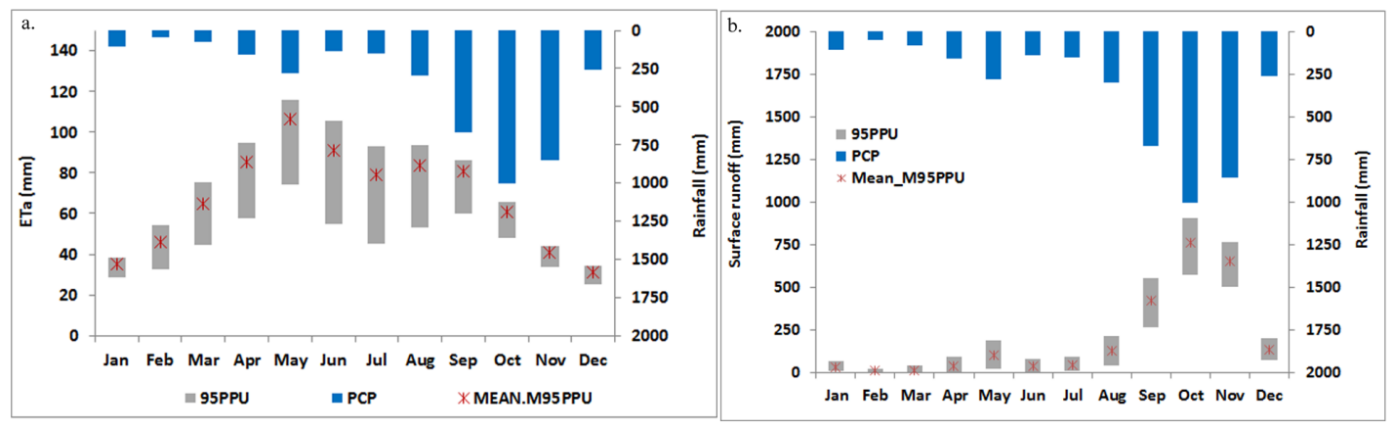

Figure 14. Average monthly (a) evapotranspiration and (b) surface runoff against rainfall. The gray bands show 95\% prediction uncertainty (95PPU) and the red stars show the median of iteration (during 2006-2013) 